\title{
CoVid-19 its Impact on Healthcare Workers and the Need for Occupational Healthcare Provision
}

\author{
Yuke Tien Fong*, Jonathan Lam WY, Chua Yeow Leng and Tay Boon Keng \\ Dept of Occupational and Environmental Medicine, Div of Medicine, Singapore General Hospital \\ *Corresponding author: Yuke Tien Fong, Dept of Occupational and Environmental Medicine, Div of Medicine, Singapore General Hospital; Email: fong.yuke.tien@ \\ singhealth.com.sg
}

Received: March 18, 2020; Accepted: March 25, 2020; Published: April 28, 2020

The world woke up in November 2019[1] to the arrival of a new "enemy" in its parade of infectious pathogens, firstly in China and in an ominous fashion, now across the globe - the coronavirus, named CoVid-19 by the WHO [2,3]. A dreaded new pandemic [4] has now announced its presence, swept through the globe with an unimaginable speed [5] and savagely wreaked havocto healthcare systems, financial sectors and lives [6] across the world.It has disrupted life as we knew it before the crisis, to an extent we have never imagined possible. The magnitude of this disaster and its multifaceted ramifications, together with its speed of spread [5] is a new and novel experience in history. Life cannot be the same again.

The healthcare worker (HCW) has now suddenly been thrown into the frontline of this storm again, battling a terrible new foe that has crossed the paradigm between its natural host to man. Many of us are not prepared for this [7]

The health of the HCW is of paramount importance in this war. The sheer lack of systemic support for the HCW is obvious in many countries. In developing countries, a lack of investment in systemic development, in manpower development, resource allocation, professional recognition and support in Occupational Health will now manifest itself and the price is costly in terms of lives. The ravage to the HCW will translate to lives lost for both the patient and the HCW. The economic impact[8] and cost of this will be in millions of lives impacted or lost $[9,10]$.

"More than 4,000 people have died worldwide [9] reaching 7529 as of 17 Mar 2020 [10] and more than 113,000 cases on $10^{\text {th }}$ Mar 2020 (reaching 184,976 as of $17^{\text {th }}$ Mar 2020) [10], have been confirmed in over 110 countries [10]. But unfortunately, the economic impacts also have dramatic effects on the wellbeing of families and communities. For vulnerable families, lost income due to an outbreak can translate to spikes in poverty, missed meals for children, and reduced access to healthcare far beyond COVID-19. While the spread in the United States and Europe absorbs much of the media coverage, confirmed cases [9] from Bangladesh to Brazil, from Cameroon to Costa Rica, and in many other low- and middle-income countries mean that many of the economic impacts may affect the world's most vulnerable populations"[8].

The outcry to develop a robust Occupational Health system that provides guidance tohealth at work [11] in particular in the Healthcare system itself, has now escalated to a scream. Where governmental and private healthcare systems did not and will not invest in this area, a desperate stage will arrive when default or demise from the frontline will lead to massive losses in healthcare provision itself for the population in a crisis. The healthcare workforce can be destitute when it goes into war with an unprepared workforce.

We need to galvanise development in this area at a rapid and sadly, crisis mode if this has not been done previously. In many countries, Occupational Medical services do not exist. Even in many modern healthcare systems, the presence of a doctor who is trained to look after HCWs within the healthcare system is itself lacking. Circumstances now prove that healthcare provision for the HCW is an essential component of healthcare delivery as it is now being tested to its limits. Our priorities need to reorganise as we realise that to win this battle, the HCW needs to survive the crisis.

The essentials of a viable Occupational Health Service within the healthcare system fundamentally comprise two critical components - a clinical service and an administrative occupational health governance / policy structure. The latter is often neglected but is essential to provide guidance and drives the priorities of the Occupational Health system. Creating the structures and funding these, providing manpower, training and logistic supportarecritical to our survival in a crisis.

One demonstration of this gap, that has become obvious even to the public,is the need for respiratory protection and personal protective equipment for the healthcare worker. Respirators and masks have become scarce resources. How many of our HCWs knew the fundamental differences between a mask and a respirator before the crisis?

HCWs can become tired and fatigued. Physical and mental exhaustion can take its toll and superheroes will also die. How about the families and psychological needs of those that toll? What is the price for heroes fallen in this travesty? HCWs are human and will also need care. We need to act rapidly. We must not forget that we too, are human. As my young colleague in the frontline opined, "We also want to live".

\section{References}

1. First Covid-19 case happened in November, China government records show report. South Morning China Post, $13^{\text {th }}$ Mar 2020. 
2. What's in a name? Why WHO's formal name for the new corona virus disease matters- WHO, $11^{\text {th }}$ Feb 2020

3. A Joint Statement on Tourism and COVID-19 - UNWTO and WHO Call for Responsibility and Coordination. WHO 27th Feb 2020

4. 4. Cucinotta D, Vanelli M (2020) WHO announces COVID-19 outbreak a pandemic. Acta Biomed 91:157-160. [crossref]

5. Wu J, Leung K, Leung GM et al. (2020) Now-casting and forecasting the potential domestic and international spread of the $2019-\mathrm{nCoV}$ outbreak originating in Wuhan, China- a modelling study. The Lancet 395: 689-697.

6. Weiss P, Murdoch DR (2020) Clinical course and mortality risk of severe CoVid19. Lancet 395:1014-1015. [crossref]
7. Chaolin Huang, Yeming Wang, Xingwang Li, Ren L, Zhao Jet al. (2020) Clinical features of patients infected with 2019 novel corona virus in Wuhan, China. Lancet 395: 497-506. [crossref]

8. The Economic Impact of COVID-19 in Low- and Middle-Income Countries. Evans, Over M. Center for Global Development (CDG), USA. 12 $2^{\text {th }}$ Mar 2020.

9. Corona virus disease 2019 (COVID-19) Situation Report - 50. WHO $10^{\text {th }}$ Mar 2020

10. Novel Corona virus (COVID-19) Situation WHO $17^{\text {th }}$ Mar 2020

11. Guidance on Preparing Workplaces for COVID-19. U.S Department of Labour Occupational Safety and Health Administration OSHA 3990-03 2020.

\section{Citation:}

Yuke Tien Fong, Jonathan Lam WY, Chua Yeow Leng and Tay Boon Keng (2020) CoVid-19 its Impact on Healthcare Workers and the Need for Occupational Healthcare Provision. Internal Med Res Open J Volume 5(2): 1-2. 